\title{
DANGER! INGOZI! GEVAAR! WHY READING ALONE CAN BE BAD FOR YOU ${ }^{1}$
}

\author{
Charlene van der Walt \\ Department of Old and New Testament \\ Stellenbosch University
}

\begin{abstract}
A discussion of the 1974 film, 'The Conversation', by Francis Ford Coppola serves as an introductory illustration of the dangers of interpretation in isolation. The film, starring Gene Hackman, highlights the contextual nature of communication, where the viewer becomes increasingly aware of the development of a skewed interpretation of an overheard conversation. Utterances and events are interpreted in isolation and perceived as ultimate truths. The social commentary offered by Coppola serves as an analogy for the dangers of exclusivist approaches to biblical interpretation. This article critiques these approaches and offers contextual intercultural Bible reading as a life giving, alternative approach that draws from the combined hermeneutical framework of Feminism and African hermeneutics. In this article I will explore the creative possibilities of the intercultural Bible reading process as a space with communal meaning-making possibilities.
\end{abstract}

Key Words: The Conversation Film; Interpretation of the Bible; Contextual Bible Reading; Intercultural Bible Reading

"I don't care what they're talking about. All I want is a nice, fat recording." It is with these words that Harry Caul (Gene Hackman), the main character in Francis Ford Coppola's 1974 film, The Conversation, states his mission concerning his job as a surveillance expert and, maybe even beyond that, it serves as a sort of credo for his life. The film, written, produced and directed by Coppola, is a timely, low-budget cinematic masterpiece of the 1970s. After his phenomenal success with The Godfather (1972), Coppola's technically brilliant, absorbing film was a critically acclaimed work, ${ }^{2}$ but it failed at the box office. ${ }^{3}$ At the 1974 Oscars Awards Ceremony, ${ }^{4}$ The Conversation competed for Best Picture with Coppola's own sequel The Godfather, Part II (1974).

Edited version of a paper delivered in the Feminist Interpretation section of the International meeting of the Society of Biblical Literature, held at the University of Amsterdam, Amsterdam, Netherlands from 22-26 July 2012.

2 The film won the 1974 Palme d'Or at the Cannes Film Festival and currently holds a 98\% on Rotten Tomatoes with an average of $8.6 / 10$ based on 43 reviews of which 42 were positive and 1 negative. Variety magazine lauded Coppola's labour of love, calling it "Coppolas's most complete, most assured, and most rewarding film up to date, and the years it took him to bring it to the screen should be considered well worth the persistence" (Cowie 1990:85). One critic called it "one of the darkest and most disturbing films ever made in this country" (Faber 1974:13).

3 This statement needs qualification. The film did very well financially, making $\$ 4420000$ in its domestic gross on a $\$ 1600000$ budget, meaning it made its budget back over 2.75 times. Although it was profitable it can simply not be compared with the blockbusters that Coppola produced at the time

$4 \quad$ It had a total of three award nominations (without any wins): Best Picture, Best Original Screenplay and Best Sound. Positioned between The Godfather Part I and Part II, the film illustrates something of Martin 
"At its most general level, The Conversation is Coppola's existential meditation on technology. ${ }^{5}$ Because technology is value-free, advancements are in themselves neutral. It is how man uses these advancements that define them as tools or weapons" (Gray 1999:125). In The Conversation, electronic surveillance is presented as a science and Harry is one of the best in the business. ${ }^{6}$ Harry Caul and his instruments function as mere tools in the war against privacy. This pawn-like position that Harry willingly finds himself in is mainly the result of his refusal to take any moral or ethical responsibility for his recordings. According to his own reasoning he merely records, with great skill and technical resources, people's conversations. These recordings mostly take place in very complex settings because of the very fact that it predominantly involves people who do not want to be overheard. After obtaining the recordings they get handed over to the interested party who pays for the information. It is a technical job and Harry works his magic for money. When confronted, amongst others by his technical assistant, Stan, about the nature of the subject matter of particular conversations, he reacts dismissively. Stan believes that it is natural to have some curiosity about the subjects in their work, but Harry asserts otherwise - he has sacrificed everything to be cold, ${ }^{7}$ calculated and methodical. ${ }^{8}$

The audience is introduced to Harry in the iconic first scene of the film. Tharp (2009) remarks the following: "The opening scene sets up the themes and underlines the dramatic tension of the film. The very first shot in the film is an astonishing three-minute long take; the camera starts wide on Union Square, San Francisco, establishing it as a major set-piece for the story - the setting where the illusory conversation takes place. The first two minutes of this shot are spent easing down into the square by a slow zoom, where the camera lens focuses in on a mime. ${ }^{9}$ The significance of the mime is to highlight the auditory disconnect from the visual in the film. When the camera is wide at the top of the shot, the sounds of the square sound distant; but as the camera pushes in, sounds like the dog barking become loud

Scorsese's credo of how to manoeuvre in Hollywood at the time, when he stated: "Make one for them (a genre film with mass appeal), then one for yourself (something small and personal)" (Peary:2000).

5 "The germ of The Conversation was a 1966 conversation with fellow director, Irvin Kershner. Coppola recalled, "We were talking about eavesdropping and bugging, and they told me about some long-distance microphones that could overhear what people were saying." Kershner sent Coppola an article about a soundsurveillance expert named Hal Lipset. Coppola was smitten. "I was fascinated to learn that bugging was a profession, not just some private cop going out and eavesdropping with primitive equipment” (Peary:2000).

6 Bernie, one of Harry's rivals drinks a toast to him declaring him as "The best bugger on the West Coast." Harry is highly regarded amongst peers and rivals alike.

7 Harry's position of isolation is further enhanced by contrasting Harry with his partner Stan. "Stan demonstrates noticeable human qualities: sex drive (takes pictures of the two women), curiosity (interest in the 'targets'" conversation), and humour (the 'Internal Revenue' pun)" (Doughery:2011).

8 Dialogue to this extent from the film illustrates Harry's ideological position.

Stan: Harry, if you filled me in a little bit, once in a while; did you ever think of that?

Harry: It has nothing to do with me and even less to do with you.

Stan: It's curiosity. Did you ever hear of that? It's just god-damned human nature.

Harry: Listen, if there's one sure-fire rule that I have learned in this business it's that I don't know anything about human nature. I don't know anything about curiosity. That's not part of what I do. This is my business... (www.filmsite.org/conv3.html).

9 The use of the mime in the opening scene of the film also creates an intertextual link with the provocative 1966 film by Michelangelo Antonioni, Blow Up. "It could be argued that the mimes in Blow Up function as ironic commentators on the photographer's protagonist's naïve faith in the visible. In this sense the appearance of their dumb fellow at the opening of The Conversation bridges the beginning and that ending at the same time that it offers a similar ironic comment on the naïve faith that Harry puts in the audible." Turner (1985:10). 
and crisp." The extraordinary sound track ${ }^{10}$ helps to draw the viewer into the scene and shows Harry being imitated by the mime, something that visibly annoys Harry since drawing attention to himself is that last thing he wants. From here on the audience is continuously linked to Harry. Peary (2000) importantly comments on this connection by stating: "Hackman's character and the audience are practically joined at the hip in this film. There is not a scene in which Harry is not the focus of action. This alliance is essential for the film if it is to succeed as a character study because Harry is a closed-off person. He does not expose himself emotionally, mentally or even physically (he sits hiding in a van or in his apartment most of the time)".

Everything about Harry is nondescript ${ }^{11}$ and practical - his generic glasses, his inexpensive suit and shoes, bargain watch and opaque plastic raincoat. ${ }^{12}$ Anonymity ${ }^{13}$ and ruthlessness are necessary to his world. Harry functions on the margin, peripheral to political, commercial or social systems. His cheap clothes are matched by his determinedly impersonal dwelling. The décor is self-consciously bland and unrevealing, though it's clear that no-one ever comes there. Throughout the film Harry demonstrates an extraordinary refusal to provide information about himself. ${ }^{14}$ "In response to his snoopy landlady's request for emergency keys to his apartment, he says: 'I would be perfectly happy if all my belongings burned up in a fire because I have nothing personal, nothing of value, except my keys" (Turner 1985:6). Denzin (1992:136) remarks in a seminal character analysis: "He takes morbid pleasure in spying on others, in wire-tapping their phones and using the latest technologies to capture their private conversation which occurs in public places. He works for anyone. He espouses no moral conscience: 'I once placed a bug in a parakeet. I don't care what they're talking about; all I want is a nice, fat recording. You get a better track if you pay attention to the recording, not what they're talking about. Just do the job. Never ask questions. Do it right. Keep your eyes and your mouth closed." Harry is a man of contradictions and is unable to communicate with anyone. "His universe is defined by sounds and their recordings." Silverman (1998:88) continues: "His fear of being overheard is as intense as his compulsion to eavesdrop on others. His favourite position is "outside the door."

Harry is hired by the Director of an anonymous corporation to tail a couple and to obtain a recording of whatever they are saying; a difficult assignment that involves

10 It is only fitting that the Sound Track of a film obsessed by 'what is heard' should be of the highest quality. "The marvellous sound work on the film was deserving of an Oscar for Best Sound for its effective sound mixing of interdependent elements: taped conversation, muffled voices, background and other mechanically generated noises, musical/piano accompaniment and other ambient sounds" (www.filmsite.org/conv3.html).

11 Gene Hackman "complained about the acute problems in becoming Harry Caul. 'It's a depressing and difficult part to play because it's low-key. The minute you start having fun with it, you know you're out of character" (Peary: 2000).

12 Gray (1999:127) remarks: "When not at home or at work, Harry wears a transparent raincoat, rain or shine, which Vincent Canby interprets as "prophylactic protection against society.",

13 Gray (1999:127) describes the state of isolation in which Harry finds himself: "Coppola's script depicts Harry residing, playing, and working in a state of isolation or near isolation. His sparsely furnished apartment has an array of locks and alarms to keep outsiders, even the building superintendent, at bay. These measures characterize a man whose trade magazine, Security World, is an understated metaphor. For recreation, Harry visits a mistress who knows no more about him than his name. He lies to her about his age; other innocent questions make him uncomfortable and he abruptly leaves. His recreation at home consists of solitarily playing his saxophone to electronic accompaniment - a recording of a jazz concert complete with applause." As an unlicensed private investigator whose focus is privacy investigation, Harry reminds one of a "shady private detective whose skills are for sale, no questions asked. He is the unheroic opposite number of the principled private eye of detective fiction". Grey (1999:128). 
recording their conversation in an outdoor setting. Harry proceeds to sets up his crew with three different long-distance microphones to record a seemingly banal conversation about Christmas presents between two clandestine lovers, who weave in an out of the lunchtime crowd on Union Square in San Francisco. The audience hears snippets of the conversation between the so-called 'targets' which is interwoven with sounds of other conversations, mingled with a saxophone solo and an off-screen band that plays: When the red, red robin comes bob, bob bobbin' along. With the use of his signature technology Harry later recreates 'the conversation' in his studio by combining the three recordings and minimalizing the other background noises. In the process of refining the recording Harry realises that he is overhearing a possible murder plot. According to the reconstructed recording something sinister is going to happen on Sunday at $3 \mathrm{pm}$ in room 773 of the Jack Tarr Hotel. Although sound bites of the conversation are played repeatedly throughout the film, it is especially the following section on which Harry fixates:

Ann: I love you.

Mark: We're spending too much time together here.

Ann: No, let's stay just a little longer.

Mark: He'd kill us if he got the chance.

Haunted by an earlier case that led to several deaths, ${ }^{15}$ Harry worries about the consequences of his assignment. In an effort to contain the situation Harry refuses to hand over the recording to the Director's assistant (Harrison Ford). While listening repeatedly to the words: "He'd kill us if he got the chance", Harry starts to fear for the young people's lives. For Harry it is obvious that the powerful Director, who commissioned the recordings, has ill intentions towards his wife and her young lover. After a late-night party the tapes disappears from Harry's studio and come into the possession of the Director. Harry is deeply afflicted. He has clearly ventured outside the safe parameters of his normal detached objective position. Harry begins to care. From never listening to what he has taped, he starts to show concern for those he is wiretapping.

The taped conversation plays in the Directors office when Harry collects his payment. On the desk is a picture of the Director with his wife Ann, dining at a restaurant. After collecting his \$ 15000 , blood money, Harry asks the Director about the fate of his adulterous wife: "What will they do to her? On the tape, Mark's voice announces her verdict for unfaithfulness - a death sentence: "He'd kill us if he got the chance."

In a final attempt to circumvent the impending, inevitable tragedy, Harry rents the room next to Room 773 in the Jack Tarr hotel at the assigned time as deduced from the recording. He uses a listening device to tap into an ongoing argument in the room next door, where he can distinguish the voices of amongst others Ann and Mark. Afflicted and overwhelmed by emotion Harry moves out onto the balcony where a bloodied hand on the partition between the rooms is the only visible sign of the fierce struggle. Harry loses control over his emotions and blacks out. He wakes up a considerable time later and the lapse in time is clear from the fact that it is now visibly dark outside. He goes to the room next door to find

\footnotetext{
The audience learns the reason for Harry's paranoia when: "The narration continues to follow Harry exclusively, and we discover the reason for his paranoia in the workshop scene with Bernie Moran. Bernie exposes Harry by telling everyone about a job Harry was on in New York that resulted in the death of a family, causing the guilt-ridden Harry to move across the country to San Francisco" (Dougherty: 2011). Denzin (1992:136) argues one of the contradictions in Harry's character when he states: "He is riddled with guilt, yet feels disconnected from the three murders that resulted from one of his jobs, 'I just turned the tapes."
} 
it empty and impeccably clean. No tangible sign of the struggle that he listened to through the wall remains. It is only when Harry flushes the running toilet that the water turns red and begins to rise - spewing forth bloodied water onto the tile floor, that his worst suspicions are confirmed. It is clear that wads of tissue paper that were used to soak up the blood have clogged the pipes.

In the final scene movement of the film, Harry and the audience, become aware of their misinterpretation. Harry reads the newspaper headlines at a newsstand: "Auto Crash Kills Executive". Looking on, Harry sees press reporters and photographers surrounding Ann as she leaves the lobby area - heir to her husband's stock, property and fortune. Harry realises with shock that he was part of the young lovers' murderous plot. Harry reflects on all the moments of interpretation realising his lack of perspective and true understanding. The words: "He'd kill us if he got the chance" now takes on its real meaning, not as an impending threat against the lovers but as a justification for their sordid plan of ill intention and ultimately murder.

I literally stumbled upon Harry Caul and his painfully tragic fate haunted me long after the end credits disappeared from screen. In the hermeneutical process of interpretation Harry was set up for failure. From within his own position of isolation, Harry approached information at face value without reflecting on the contextual nature of the utterances in the conversation. Plagued by his own guilt Harry interprets the conversation from his own biased position without testing his interpretation with his assistant Stan or any other peers. Harry fails to consider the influence of his own history of interpretation and the effect that it has on any new process of interpretation. This uncritical, self-centred and self-sufficient space from which Harry interprets the conversation leaves no room for alternative points of view or other possible meanings to develop. Harry can see no interpretive reality beyond his own and even more troubling is the fact that Harry is utterly unaware of his own unique experience-fuelled position of interpretation. Harry thinks he knows the truth; he is painfully unaware of the partial and contextual nature of his so called truth.

It is not only his own context that Harry does not consider in the process of interpretation; he also seems blind to the contextual situatedness of the so called 'targets'. Turner (1985:12) illustrates this when arguing: "It is clear that the inflection upon a given pronoun - such as 'us' in 'he'll kill us if he gets the chance,' can radically alter the semantic content of the sentence in which it is enunciated. In this sense the error committed by Harry Caul was to fail to understand the position of the speaker, or enunciator, of his tell-tale tape. Locked into his own subjectivity - his own narrative of selfhood - he reads things as if they had been articulated as pure denotation, devoid of the shading and nuance of discourse."

Apart from not considering his own contextual position or that of his 'subjects', Harry also ignores the multiplicity of meanings located within a specific 'text'. Although the text is but one line, in this case: "He'd kill us if he got the chance", it clearly illustrates the plurality of distinct structured 'meaning producing dimensions' within the text. Daniel Patte $^{16}(1995: 28)$ argues in this regard: "Each of these meaning-producing dimensions

16 Daniel Patte draws heavily on the work of Mieke Bal in this regard. Bal, on the basis of semiotic theories, shows how a diversity of meanings is possible as it depends on the choise of different 'codes' as foci of critical investigation. "Each of these codes reflects concerns and interests of certain groups in specific contexts and is studied through the use of a specific critical method" (Patte 1995:27). Bal (1987:132) remarks in terms of her own scholarship: "My readings present an alternative to other readings, not a 'correct' one, let alone the 'only possible' interpretation of what the text 'really says.' Texts trigger readings; that is what they are; the occasion of a reaction. The feeling that there is a text in support of one's view makes texts such 
offers readers/interpreters the possibility of perceiving a coherent meaning for the text. Different readers, because of their specific interests, concerns or backgrounds, perceive different yet coherent meanings in the text (or better, produce these meanings with the text) by selecting one of these dimensions of the text." As a result of his isolation and lack of self-critique, Harry cannot allow himself to affirm the legitimacy of a plurality of interpretations. He cannot bring himself to acknowledge the fact that where you stand determines what you see.

Finally, as mentioned above, Harry's blind devotion to his method of interpretation leaves him ethically vulnerable. Harry fails to see that his interpretation of the "nice fat recording' has very real consequences for the people involved, not only those that he is listening to, but ultimately also those he are listening for. ${ }^{17}$

Harry's unfortunate position of interpretation and the dismal consequences thereof, served as an important reflective surface to consider the often similar challenges faced by various interpreters of the Bible. Like Harry many Bible readers, knowingly or unknowingly, function in interpretative isolation, either oblivious to or denying the possibility of interpretations other than their own and by doing this claiming legitimacy only for their own reading and understanding of text. This position of interpretative isolation is evident in the normative and universal claims of Androcentric en Eurocentric Biblical Scholarship ${ }^{18}$ as well as the exclusivist interpretative statements of fundamentalist faith communities. ${ }^{19}$ When considering the values of traditional Biblical Scholarship and looking back at its history, ${ }^{20}$ it is clear that a privileged position of power was long held by

efficient ideological weapons. Every reading is different from, and in contact with, the text... (T)he point is that there is none, at least not one single one; the point of literary analysis is that there is no truth, and that this contention can be reasonably argued."

17 For further critical reflection in this regard, especially focusing on the South African context, please see the work of the South Africa scholar Gerrie Snyman. Snyman, G 2007. Om die Bybel anders te lees. ' $n$ Etiek van Bybellees. Pretoria: Griffel. Snyman explores the impact of interpretation on reading communities as well as those who are interpreted for by drawing on amongst others Emmanuel Levinas's concept of the Other and J Hillis Miller's concept of the law of the text. Snyman's work offers invaluable reflection on themes related to rhetoric and ethics especially by engaging issues such as race, class and gender.

18 Patte (1995:29) argues as follows in this regard: "These terms (Androcentrism and Eurocentrism) express the fact that the male and European perspectives, approaches, methods, and interpretations are taken to be normative and universal and therefore posited as the only legitimate ones".

19 In the process of reflecting on her own experience within the Neo-Pentecostal tradition, Sarojini Nadar (2009:137) summarises the guiding principles to the appropriation of Scripture as follows: “However, from the Pentecostal approach to Scripture has emerged a sustained and developed neo-Pentecostal understanding of Scripture - what I have termed 'the four i's' approach. This approach suggests that the Bible is inerrant, infallible, inspired and immediate." Elsewhere Nadar (2004:359) continues: "This idea of the Bible as the indisputable word of God, which has no need of critical or contextual interpretation, is directly linked to the idea that the Spirit enables interpretation, and that the interpreter is simply an innocent unmediated voice of the Spirit. "I try to give them the Bible, not just what I think," is a typical statement made by Pentecostal preachers." Interpreters in this tradition thus share something of Harry's ignorance concerning their own inevitable situatedness within the process of interpretation.

20 Throughout the course of history, different strategies have been used to interpret biblical text. Broadly speaking, four main phases of biblical scholarship can be distinguished. Each phase focuses on a different aspect of the interpretation process:

- Historical-critical approach: the world behind the text. In this approach to biblical interpretation, the focus is on the description of the text in terms of its process of development and the world in which the author/s functioned. Louis Jonker (2005b:27) describes this movement as follows: "The historicalcritical approaches hold in common the presupposition that (biblical) texts can and should be understood only in the light of the historical context within which they originated." 
the practitioners of Western academic scholarship. The language, themes of discussion and focus of investtigation were determined mainly by the few who had access to the academic environment. Sure of their methods and seemingly unaware of the influence of their contextual situatedness on their interpretation they continue to interpret text oblivious of how their interpretations impact on those they interpret for or on behalf of. ${ }^{21}$ In doing so interpreters ignore the multidimensional nature of text, as Daniel Patte (1995:9) argues: "I argue for the plausibility of acknowledging that any reading, including any critical reading, is the production of meaning by the reader with one or another of the meaning-producing dimensions of the text, consciously or subconsciously chosen because it matches the interest or concerns of the reader... I argue for the plausibility of recognising that the diverse readings based upon different meaning-producing dimensions of a text are equally legitimate because none of these dimensions can be said to be a more legitimate representation of the meaning of the text than the others."

The result of Harry's skewed interpretation is the death of a man due to two lovers' murderous plot. A plot communicated to Harry in so many words, but one that he failed to grasp fully. When considering this painful reality one inevitably asks, What could have prevented this? What parameters could have been put into place to help Harry read the text more responsibly and with greater accountability? And if one uses Harry as an example for practitioners of exclusive enterprises of biblical interpretation, the question also extends to the practise of biblical interpretation, namely what do we need to do or put into place to counter exclusive practices of biblical interpretation? How do we create a life-affirming alternative?

When reflecting on Harry's situation it is clear that he could have done well with a diverse community surrounding him and journeying with him in the interpretative process; a community with a diversity of skills and who represent diverse interpretative positions or location. A healthy dose of self-critique and critical reflection could have also helped Harry; by being more critical of himself Harry would have discovered the contextual nature of his own interpretation, the contextual situatedness of his subjects and the multiplicity of meanings located within contextually embedded utterances. Finally Harry would have ended up in a much better place if he considered the ethical implications of his interpretative practise. Daniel Patte's (1995:29) challenges for biblical scholars resonate

- Literary approach: the world of the text. The text itself becomes the main focus of biblical scholarship.

"A text is a unique linguistic unit, constituted by the relationship of the parts to one another and to the whole. Whereas historical criticism regarded meaning as a function of origin, those who turned to the text itself regarded meaning as a function of the relationships among the parts of a text" (Lawrie 2005a:68).

- The role of the reader in the interpretation process: the world in front of the text. In this approach, the role of the reader is taken seriously. "The reader does not merely discover meaning, but plays an active part in the creation of meaning" (Lawrie 2005b:110). Moreover, readers read text not in isolation but as a function of the constant interaction between the text and the reader's personal context. The context of the reader becomes the key to the understanding of text. "The specific context of the reader provides the horizon of understanding that enables the reader to make sense of the text" (111).

- Hermeneutics of suspicion: the world under the text. "A number of influential approaches to the interpretation of texts are based on the suspicion that there are hidden factors at work in the production, circulation and reception of texts." Douglas Lawrie expounds on this: "The hermeneutics of suspicion suspects that what usually remains hidden is indeed a guilty secret. Neither authors, nor texts, nor readers are 'innocent' or neutral. They often work together to keep up the (false) appearance of normality and rationality" (2005c:167). For further reflection on the notion that the interpretations by some could bear marks of the 'others' please see: Phillips, GA \& Fewell, DN 1997. "Ethics, Bible, reading as if." Semeia, 77:1. 
with the above-mentioned: "What is needed is a practice of biblical study that accounts for the multiplicity of readings, related to the variety of contexts from which readers read."

Linking up to Daniel Patte in this regard and using Harry's fate as an example of the results of exclusive approaches to Biblical scholarship, I would like to propose the intercultural Bible reading space as a life-affirming alternative to exclusivist approaches to biblical interpretation.

The intercultural Bible reading space theoretically develops out of the combined hermeneutical framework of Feminism and African hermeneutics. Whereas Feminism argues for the importance of the contextually embedded voice of the individual ${ }^{22}$, African hermeneutics ${ }^{23}$ theoretically offers a communal space where the voice of the individual can be heard. The space that African hermeneutics describes, allows for the transformation from a situation of multiculturality to interculturality, where the differences between various cultural agents are not merely tolerated but rather celebrated and where they are brought into real interaction. African hermeneutics thus asks for an ethic of hospitality. ${ }^{24}$

The praxis of the intercultural Bible reading process therefore implies the coming together of diverse individuals from different cultural backgrounds within a safe space that allows for the interaction between these individuals and the culturally diverse Biblical text. $^{25}$

22 In Ackermann's (1993:24) definition of Feminism, the inclusivity of the term is made clear. Feminism is described as follows: "The commitment to the praxis of liberation for women from all that oppresses us. Feminism does not benefit any specific group, race or class of women; neither does it promote privilege for women over men. It is about a different consciousness, a radically transformed perspective which questions our social, cultural, political and religious traditions and calls for structural change in all these spheres." The importance given to the contextuality of individual voices grows out of one of the fundamental principles of Feminism namely the central role of women's experience. Ackermann describes the importance of this principle for a feminist hermeneutic as follows: "A feminist hermeneutic, like all hermeneutics, is grounded in experience, and more particularly in women's experience of oppression... It is essential to acknowledge that experience itself is interpreted and filtered through our cultural matrix, which in turn is formed by the race, class, time and histories of our lives. There is no universal experience for all people or even for all women. Yet, while accepting the particularity of experience as a hermeneutical category, we must acknowledge the universal fact of discrimination against and oppression of women" (Ackermann 1993:21).

The term African hermeneutics does not imply a singular all-encompassing movement or approach to theological issues. Africa is fragmented and approaches to theological issues are numerous. Pluralism is of course not unique to Africa, but rather typical of a post-modern reality, a reality that challenges the universalisation of human experience. "Resistance to this universalising and imperialist tendency, therefore, means an assertion of the radically, irreducibly plural nature of human existence. It implies a fundamental respect for the Other, one that does not and will not attempt to reduce the Other to the Same. Life is basically dialogical, like a good conversation. It is a relation that retains its distance; it is a face-to-face engagement that respects the 'otherness of the other'; it is committed to hearing the voice of the other. Pluralism, thus, is a given fact of political, cultural, theological and religious life" (Peterson 1994:223). African hermeneutics takes diversity seriously and does not strive towards the creation of a new approach to biblical interpretation, but as Jonker rightly states: "An African hermeneutic is rather a hermeneutical stance or disposition according to which, and in service of which, a whole variety of exegetical methods or tools are used" (Jonker 2005a:637-650).

24 As Vosloo (2003:66) proposes: "The challenge posed by the moral crisis does not merely ask for tolerance and peaceful co-existence or some abstract plea for community, but for an ethos of hospitality. The opposite of cruelty and hostility is not simply freedom from the cruel and hostile relationship, but hospitality. Without an ethos of hospitality it is difficult to envisage a way to challenge economic injustice, racism and xenophobia, lack of communication, the recognition of the rights of another, etc. Hospitality is a prerequisite for a more public life."

25 The intercultural moment thus lies on two levels: on the one hand lies the difference between various cultural frameworks that Jonker (2010:53) describes as follows: "Intercultural hermeneutics therefore takes its point of 
In conclusion I would like to highlight a number of assets that the intercultural Bible reading space possesses which could serve as counter-measures in order to minimalise the possibility for exclusivist practises of Biblical interpretation and in the process resist the life-denying consequences thereof.

\section{A Diversity of Voices}

The intercultural Bible reading space poses challenges for the traditional bipolar model ${ }^{26}$ that is used to explain the hermeneutical process. Kessler (2004:452-459) problematises all three traditional elements involved in the hermeneutical process, but he primarily indicates how the role of the reader is challenged by the intercultural Bible reading process: "In the traditional model, the reader is understood to be singular - one reader... In contrast, within the process of Intercultural Bible reading, the position of the reader becomes plural. By definition, the reader is no longer an individual or a single group, but multiple readers who are linked together. The receiver of the text is not a single pole in this hermeneutic model it is a plurality of poles."

Kessler (2004:457) goes on to describe the unique position of the reader in the intercultural Bible reading process as follows: "These readers do not simply have the text as object of interpretation; they have other readers with whom they communicate. Reading the text thus becomes a double communication. It is communication with the text, as in the traditional bipolar model. And by means of the text, it is communication with the author. However, reading also includes communication with other readers. This communication forms a constitutive part of the process of understanding. Understanding the text is no longer possible without the communication with other readers. Through intercultural Bible reading, these other readers are no longer readers who come from the same context. These readers are different from one another and they are global."

Interpreters with a diversity of skills thus come together to hold each other accountable for their contextually embedded readings of text and to serve one another with their interpretative skills. ${ }^{27}$ Within this space there is a place for both scholarly and lay readers, it regards the differences in these reading populations as an assent that holds the potential for life-affirming praxis. West (2007:2) remarks in this regard: "Part of the substantive claim I am making in differentiating between the scholar and nonscholar/ordinary reader is that there is a difference in the way each of these sectors read biblical texts. This difference is significant, and recognition of this difference can lead to creative and socially transformative collaboration between different sets of interpretive resources these different

departure in the interaction, the communication between different cultures", and on the other hand the interaction between diverse modern Bible readers and the culturally removed Biblical text.

Kessler (2004:452) describes the traditional bipolar model as follows: "The traditional hermeneutical model may be called bipolar. The centre of this model is always the text, which may be written or spoken, although biblical texts are, of course, written texts. One pole of the bipolar model represents the text's author... The second pole of the bipolar model represents the receiver of the text."

27 Musa Dube (2000:116) describes this quest for new creative spaces for interpretation when defining Postcolonial Feminism as an endeavour that "must always insist on new spaces for cultivating new contextual and international reading-writings, which are both decolonising and depatriarchalising. As used here, new spaces, therefore, define new frameworks of imagining reality and building social, economic and political structures that do not espouse patriarchal and imperial forms of relationships, or any form of oppression. Such new spaces demand the courage to constantly plant new seeds of critical assessment of social structures and build relationships of liberating interdependence. The vibrancy of such spaces will require embarking on a deliberate agenda of monitoring and resisting all forms of oppression." 
sectors bring to a collaborative reading project. So, in the general sense I am focusing on the kind of interpretive training different sectors have received. The ordinary reader has been 'trained' by his or her primary (for example, the family) and secondary (for example, the church and school) communities, whereas the scholarly reader has been trained by a tertiary community, the academy."

The rich diverse intercultural space thus serves as a counter for the dangers of reading in isolation by exposing interpreters to each other and in so doing highlights the multiplicity of interpretation possibilities.

\section{Serious about Context}

One of Harry's most serious flaws in the process of interpretation is his lack of contextual awareness. Contextuality implies more than the mere context of interpretation or the context of the interpreter. Jonker (2005a:640-641) unpacks this term and alludes to the following contexts that need to be taken into account in the process of interpretation.

- Productive Contextuality: one first has in mind all those different contexts, spanning over ten or more centuries, within which all the diversity of biblical literature was produced.

- Rhetorical Contextuality: refers to those realities that are constructed in biblical texts.

- Literary Contextuality: is manifested in the various literary contexts that are embodied in the corpus of biblical writings.

- Canonical Contextuality: in the final formation of the Bible ... there were various theological considerations that interacted with socio-political conditions in order to bring about what is called the biblical canon.

- Meta-theoretical Contextuality: since the conclusion of the canonisation processes various traditions of interpretation of the Bible have emerged.

In order to allow for this diversity of contexts to come into play in the interpretation process, an intercontextual model should be pursued: "What we should be looking for is not in the first place contextual authenticity, but rather contextual integrity, that is, an approach to biblical interpretation that brings into interaction all those dimensions of contextuality that inform our life interests as well as our interpretative interests" (642).

Both Jonker (2005a:645) and Patte (1995:28) argue for a multidimensional, critical, communal approach to biblical interpretation. According to Jonker, "A communal approach would rather appeal to the diversity of (South) African scholars to come to the liminal space of community in order to share, to contradict, to influence, to change one another's interests in terms of the whole spectrum of contextualities involved in biblical interpretation."

The communal space that is inherent to the intercultural Bible reading process holds the possibility of being a space that takes a diversity and the interply of different contextualities seriously. The rich diverse intercultural space thus serves as a counter for the dangers of reading without considering contextuality. 


\section{Not merely doing no Harm, but rather making Change possible}

By allowing for the interaction among culturally diverse individuals, the intercultural Bible reading process theoretically becomes a safe space that promotes human dignity and facilitates social transformation.

The primary potential contribution that the intercultural Bible reading space could make is the creation of a safe space where both women and men can engage with complex cultural realities and the ramifications thereof, from within the confines of a caring and supportive environment. White (1997:141) suggests that when people stand together in solidarity, however briefly and partially, it “... provides us with the opportunity to look back on our taken-for-granted ways of thinking and being in the world." He further believes that this makes it possible for people to "think outside the limits of what we would otherwise think, to challenge aspects of our own participation in the reproduction of dominance, and to identify options for action in addressing disadvantage and inequality that would not otherwise be available to us" (White, 1997:141). By becoming a space that holds a diversity of interpretative opinions it presents the potential for a unique experience of community.

By reading Biblical text together the intercultural Bible reading space thus serves as a counter for harmful exclusivist interpretative practices.

\section{Conclusion}

In contrast to the community described above that develops through the process of intercultural Bible reading, at the end of the film we find Harry emotionally bankrupt and completely isolated, the tragic anti-hero; alone and paranoid. Copula's meditation on the interpretation process leaves the viewer with difficult questions and at least one important warning: Danger! Ingozi! Gevaar! Reading alone can be bad for you...

\section{BIBLIOGRAPHY}

Ackermann, DM 1993. "Meaning and Power: Some Key Terms in Feminist Liberation Theology." Scriptura: International Journal of Bible, Religion and Theology in Southern Africa, 44:19-33.

Bal, M 1987. Lethal Love: Feminist Literary Readings of Biblical Love Stories. Bloomington: Indiana University Press.

Cowie, P 1990. Coppola. New York: Scribner's.

Denzin, NK 1992. The Conversation. Symbolic Interaction, 15(2):135-150.

Dougherty, P 2011. "A nice fat Recording" The Conversation Movie Review. Online.

Faber, S 1981. "A Nightmare World with no Secrets." Review. New York Times 12 May II:13.1.

Dube, MW 2000. Postcolonial Feminist Interpretation of the Bible. St Louis: Chalice Press. Gray, WR 1999. Tuning in to The Conversation: Twenty-five Years Later. The Journal of Popular Culture, 33(2):123-130.

Jonker, LC 2005a. “'Contextuality' in (South) African Exegesis: Reflections on the Communality of Our Exegetical Methodologies." Old Testament Essays 18:637-50. 
--Jonker, LC 2005b. “Approaches Focusing on the Production of Texts.” In Fishing for Jonah (Anew): Various Approaches to Biblical Interpretation, edited by Louis C Jonker and Douglas Lawrie, pp. 27-66. Stellenbosch: SunPress.

- Jonker, LC 2010. "The Global Context and Its Consequences for Old Testament Interpretation." In Global Hermeneutics? Reflections and Consequences, edited by Louis C Jonker and K Holter. IVBS Proceedings 1:47-56. Atlanta: SBL (electronic publication: http://ivbs.sbl-site.org/uploads/JONKER 1.PDF).

Kessler, Rainer 2004. "From Bipolar to Multipolar Understanding: Hermeneutical Consequences of Intercultural Bible Reading." In Through the Eyes of Another: Intercultural Reading of the Bible, edited by Hans de Wit, Louis C Jonker, Marleen Kool, and Daniel Schipani, pp. 452-59. Elkhart, IN: Institute of Mennonite Studies.

Lawrie, G 2005a. "Approaches Focusing on the Texts Themselves." In Fishing for Jonah (Anew): Various Approaches to Biblical Interpretation, edited by Louis C Jonker and Douglas Lawrie, pp. 67-108. Stellenbosch: SunMedia.

Lawrie, G 2005b. “Approaches Focusing on the Reception of Texts.” In Fishing for Jonah (Anew): Various Approaches to Biblical Interpretation, edited by Louis C Jonker and Douglas Lawrie, pp. 109-66. Stellenbosch: SunMedia.

Lawrie, G 2005c. "The Hermeneutics of Suspicion: The Hidden Worlds of Ideology and the Unconscious.” In Fishing for Jonah (Anew): Various Approaches to Biblical Interpretation, edited by Louis C Jonker and Douglas Lawrie, pp. 167-228. Stellenbosch: SunMedia.

Patte, D 1995. Ethics of Biblical Interpretation: A Re-evaluation. Louisville: Westminster.

Peterson, R 1994. "Theological and Religious Pluralism." In Doing Theology in Context: South African Perspectives, edited by John W De Gruchy and Charles VillaVicencio, pp. 219-228. Maryknoll: Orbis Books.

Phillips, GA, \& Fewell, DN 1997. Ethics, Bible, reading as if. Semeia, 77:1

Silverman, K 1988. The Acoustic Mirror: The Female Voice in Psychoanalysis and Cinema. Indiana University Press.

Snyman, G 2007. Om die Bybel anders te lees.'n Etiek van Bybellees. Pretoria: Griffel.

Nadar, S 2004. On being the Pentecostal Church. The Ecumenical Review, 56(3):354-367.

Nadar, S 2009. “The Bible Says!” Feminism, Hermeneutics and Neo-Pentecostal Challenges. Journal of Theology for Southern Africa, 134:131-146.

Peary, G 2000. The Conversation. Review. Online: www.geraldpeary.com/essay/the/the_conversation.htmle Conversation

Tharp, C 2009. The Conversation [Francis Ford Coppola] Scene Analysis. Online: http://cinemaarts.blogspot.com/2009/11/conversation-francis-ford-coppolascene.html

Turner, D 1985. The Subject of The Conversation. Cinema Journal, pp. 4-22.

Vosloo, R 2003. "Public Morality and the Need for an Ethos of Hospitality. Scriptura: International Journal of Bible, Religion and Theology in Southern Africa 82:63-71.

West, GO 2007. Reading Other-Wise: Socially Engaged Biblical Scholars Reading with Their Local Communities. Atlanta: Society of Biblical Literature.

White, M 1997. Narratives of Therapists' Lives. Adelaide: Dulwich Centre Publications. 